\title{
Peatlands Restoration As A Potential Solution To Resolve Peatlands Damage Based On Sustainable Development Goals (SDGS) In Sungai Tohor, Indonesia
}

\author{
${ }^{1}$ Tito Handoko, ${ }^{2}$ Tiyas Tinov, ${ }^{3}$ Achmad Fajri Febrian, ${ }^{4}$ Risky Arya Putri, ${ }^{5}$ Frini Karina Andini, ${ }^{6}$ Ogi \\ Rifansyah \\ ${ }^{1,2}$ Department of Government Studies, Universitas Riau, Indonesia \\ ${ }^{3,5,6}$ Department of Business Administration, Universitas Riau, Indonesia \\ ${ }^{4}$ Department of Public Administration, Universitas Riau, Indonesia \\ e-mail: tito.handoko@lecturer.unri.ac.id,
}

\begin{abstract}
Peatland restoration is a potential solution to resolve peatland damage but faces an economicsocial-environmental exchange (Sustainable Development Goals) that results in strong disagreements between stakeholders who have different interests such as company, community and local or regional government concessions. Successful peatland restoration will depend on how various priorities have been reconciled, as much as it depends on improving governance and cross-sector collaboration well done. The purpose of this paper is to find a solution how to be managing peatlands in Sungaitohor, Indonesia. We use social maps to show the communities concern to restoration of degraded peatland, we try to compare the level of public awareness to prevention efforts and the restoration of peatland damaged by fires Forest and peatlands. The findings of this paper are social map, that explain the community's participation to efforts of peatland restoration in Sungai tohor, Indonesia.
\end{abstract}

Keywords: Peatland restoration, economic, social, environmental, sustainable development goals

Abstrak

Restorasi lahan gambut adalah solusi potensial untuk menyelesaikan kerusakan lahan gambut tetapi menghadapi pertukaran ekonomi-sosial-lingkungan (Tujuan Pembangunan Berkelanjutan) yang menghasilkan ketidaksepakatan yang kuat antara pemangku kepentingan yang memiliki kepentingan yang berbeda seperti konsesi perusahaan, masyarakat dan pemerintah lokal atau regional. Restorasi lahan gambut yang berhasil akan tergantung pada bagaimana berbagai prioritas telah direkonsiliasi, sebanyak tergantung pada peningkatan tata kelola dan kolaborasi lintas sektor yang dilakukan dengan baik. Tujuan dari makalah ini adalah untuk menemukan solusi bagaimana mengelola lahan gambut di Sungaitohor, Indonesia. Kami menggunakan peta sosial untuk menunjukkan kepedulian masyarakat terhadap pemulihan lahan gambut yang terdegradasi, kami mencoba untuk membandingkan tingkat kesadaran masyarakat dengan upaya pencegahan dan pemulihan lahan gambut yang rusak oleh kebakaran Hutan dan lahan gambut. Temuan dari makalah ini adalah peta sosial, yang menjelaskan partisipasi masyarakat terhadap upaya restorasi lahan gambut di Sungai tohor, Indonesia.

Kata Kunci : Restorasi lahan gambut, tujuan ekonomi, sosial, lingkungan, dan pembangunan berkelanjutan 


\section{INTRODUCTION}

Nowdays, peatland damage is a critical issue in the world. Forest and land fire disasters in Indonesia reached 89,563 hectares out of a total of 328,724 hectares burning by the end of August 2019, and most of it was peatland forests (Metaragakusuma, Katsuya, \& Bai, 2016). Fires in peatland forests are much more difficult to deal with compared to fires that occur in high-level mineral soil forests. This is caused by the spread of fire which not only occurs in the ecosystem on peat but also occurs in peat soils which are difficult to determine (Ming, Sobeng, Zaini, \& Busri, 2018).

Indonesian peat swamp forests cycle and store globally significant amounts of carbon. They provide essential ecosystem services, including regulating water across the landscape and buffering salt/freshwater transitions in coastal areas. They host unique and often endangered species such as orangutans and provide critical habitats for migratory birds. Local people traditionally benefit from peat swamp forests for timber to build their houses, nutrient-rich wild food and fish to supplement their diet, clean water and access to medicinal plants. These natural riches can also be a source of income and wellbeing (Nusawakan, Kunu, \& Luhukay, 2017).

Peat forests and the ecosystem services they provide are being transformed at a critical rate between 2007 and 2015 the rate of loss was 2.6\% per year in Sumatra and Kalimantan (Hariyanto, 2016). Growing demand for arable land, in particular for palm oil production, lack of suitable unused uplands, and the attractiveness of peatlands' availability and flat topography (as opposed to alternative upland steep hills that present erosion risks), have all led to intense conversion and drainage of peatlands in recent decades. Weak and unclear land tenure has likewise prompted overlapping land claims between individuals, communities, companies and governments, consequently facilitating their appropriation. Peatlands now represent a contested frontier region (Laufa \& Kavanamur, 2008; Metaragakusuma et al., 2016).

In response to global markets, oil palm has become one of the most economically attractive crops to cultivate in humid tropical regions. Yet the national benefits of peatland-generated palm oil, including the full costs associated with degradation, fires and restoration, have not been systematically analyzed. Indonesia is the leading global producer of crude palm oil with a production rate growing exponentially over time (Muhidin, Leomo, Alam, \& Wijayanto, 2016). The contribution of oil palm expansion to peatland deforestation also tends to follow an exponential pattern (Miettinen et al. 2016), even though oil palm development is not the sole driver behind peat swamp forests disappearing.

In the past 10 years, the use of peat forests has had a variety of negative impacts on the environment and the most highlighted impact among environmentalists is the increase in GHG emissions from peat decomposition and fire. History shows the worst forest and land fires in Indonesia. Especially in Riau Province, which occurred in 2015, which took place from June to November, has caused a loss of around 221 Trillion Rupiahs with $\pm 37 \%$ of the 2.6 million hectares of land burned is peat land (Ming et al., 2018).

The largest peatland in Riau Province, located in the Meranti Islands Regency with an area of \pm 318,234 ha, from $\pm 370,800$ ha of land area, meaning that some $75 \%$ of the land in Meranti District is peatland. The most extensive peatland sub-districts are Tebing Tinggi Timur sub-district covering 72,628,000 hectares, and Merbau sub-district 59,146,000 hectares, with a depth of 4 - 12 meters (Jong, 2018).

In 2013 there were quite large forest and peatland fires in the Meranti Islands Regency. Peatland fires that occur are caused by land clearing and burning by companies and interest groups. Some 2,000 hectares of peatlands have been drained without canal closure. One large company that cleared land by burning was in Sungai Tohor Village. Other than that. Sungai Tohor Village has peat characteristics with a deep peat dome. Great losses were felt by the people of Sungai Tohor Village because the community's sago gardens were also burnt so that the community had lost their livelihoods. In addition, peatland fires 
also cause conflicts between communities and companies. Issues regarding land compensation also trigger conflicts that cannot be resolved (Muhidin et al., 2016)

This article has a purpose, that it is to provide a synthesis of research-based knowledge to a wide range of practitioners, including policy makers; and highlight key gaps for the scientific community. This article also will produce a peatland management solution to be useful for strategic planning, and policy development and implementation for Indonesian sustainable development goals.

\section{METHOD}

This research focuses on the Peatlands Restoration as a Potential Solution to Resolve Peatlands Damage Based on Sustainable Development Goals (SDGs) in Sungai Tohor in Riau Province, Indonesia. The research method used is a quantitative and qualitative approach within depth exploration on the research object of an analysis of the social, economic and environmental aspects in peatland restoration. The process used was a qualitative survey method with 264 participatory observation techniques through live in activities in Sungai Tohor Village, Kab. Meranti, Riau Province. Then, we use key important informants to measurement a research focus on this research (Sharma \& Kharub, 2015).

The informants used were several communities and actors related to the informants who managed peatlands in the Tohor River, Riau Province, Indonesia. The type of research approach is participatory qualitative with live in for 2 months in Sungai Tohor village. During Live in at the research location, namely in Sungai Tohor Village, Kab. Meranti, qualitative data is stored in a diary. Daily notes or field notes are the main instruments attached to a variety of qualitative data collection techniques (Creswell, 2010).

The study was conducted on research target groups who were directly involved and knew the process of management, restoration and revitalizing peatlands that were burning and damaged. The process used was a qualitative survey method with participatory observation techniques through live in activities in Sungai Tohor Village, Kab. Meranti, Riau Province.

\section{FINDING AND DISCUSSION}

\subsection{Deforestation, drainage and conversion to agriculture}

Reclamation of peatland or peat swamp forest in Sungai Tohor Village started since 2014. Forests were depleted as a result of large government programs (e.g. transmigration), unmonitored legal logging in concessions and extensive illegal logging. Drainage canals were built to enable agricultural development and the transportation of logs. These canals provided access deep into remaining unlogged forests. They led to the draining of extensive areas of peatland, leaving them dry and exacerbating fires.

The peatlands restoration program launched by the Government has drawn a variety of reactions by many communities. Action research in Sungai Tohor Village saw that the peat restoration policy was welcomed positively by the community. This can be seen from the level of knowledge and community participation and involvement in peat restoration efforts in Sungai Tohor Village. Data obtained by researchers explain that the public is aware of the regulations issued by the government, especially those relating to Government Regulation No. 57 of 2016 concerning Management and Protection of Peat Ecosystems. The regulations issued are not only known but are also applied by the people of Sungai Tohor Village. Community knowledge is also supported by community participation in managing peatlands as agricultural land and maintaining peatlands so that they continue to be wet and prevented from fires (Nusawakan et al., 2017). 
The use of peatlands as agricultural land for sago production is carried out by most residents of Sungai Tohor Village. About $98 \%$ of people make this their main livelihood. Communities use peatlands as sago production areas for sustainability and economic prosperity. The peat restoration program launched by the Government since 2014 has attracted various reactions from the community. This community reaction is expressed as a form of response that has two points of view, namely positive and negative.

Community response is a consequence of previous behavior as a response or answer to a problem. The response is a reaction in the form of acknowledgment or rejection and indifference to what is conveyed by the communicator through his message. Responses can take the form of opinions, and attitudes that are open answers to a problem are expressed in words spoken or written that describe positive or negative reactions to certain people, objects or situations.

Smallholders are key stakeholders in the peatland landscape, yet improvement of sustainable livelihood options for them has been largely disregarded. Livelihoods of Indonesian smallholders in peatland areas are diverse. They are mainly based on natural resources, including forestry, fisheries, agriculture and mining; with a share of these activities varying widely across regions (Noor et al. 2005). Local communities commonly extract timber and non-timber forest products, such as wild honey, resins and rattan (Anshari and Armiyarsih 2005). The high dependence of some local communities on revenues from timber extraction has induced overexploitation of peat forests and depletion of resources. Timber is usually sold locally at very low prices, especially when derived from illegal operations.

Agriculture is an important source of income for rural communities. Rearing of livestock (cows, goats, sheep and buffaloes) is small-scale and traditional. Efforts to introduce alternative livestock-based livelihoods for resource diversification have been limited and their success minimal, in part due to high disease prevalence. Agricultural and agroforestry practices are constrained by the hydrology and poor soil properties (high acidity, low nutrient content) of peatlands. Smallholders most commonly use draining and slash-and-burn practices for agriculture.

They often take advantage of existing drainage canals built up by logging, oil palm or pulp and paper companies. Crops and trees commonly grown by rural smallholders, especially migrants, include oil palm, rice, rubber (Hevea brasiliensis) and rattan. Smallholders prefer to plant rice (as a staple food) and oil palm (as a cash crop), even though the burning and draining practices required to grow these crops bring negative environmental consequences that are extremely costly to reverse. For the cultivation of rice or other annual crops, land is regularly burnt, causing significant soil losses and greenhouse gas (GHG) emissions. This will likely continue, if knowledge about the impacts of draining and burning peatlands is low, and while economic options for more sustainable use of peatlands remain limited.

The diverse ways in which peatlands are used by smallholders and larger-scale industries results in wide-ranging GHG footprints; however, all uses that employ drainage lead to longterm huge GHG emissions. Drained secondary forest and shallowly drained Sago palm plantations are the smallest emitters. The land use with the highest ecological footprint is the industrial Acacia plantation. Acacia is a nitrogen-fixing species exploited under deep drainage and over short rotation periods (six years). Annual peat emissions of GHG in oil palm plantations, croplands and rice fields are similar in magnitude.

\subsection{Sustainable Development Goals in Peatland Restoration}

A study on the political economy of fire and haze was conducted to understand the forces driving fires in Riau- Sumatra, a province that has experienced both fires and forest transition to oil palm plantations (Purnomo et al. 2017). Social, political and economic data were collected from surveys in former fire sites, and group discussions were held with key stakeholders. Stakeholders included governments, who develop and implement fire policies; actors involved in business and experienced in using fires; non-governmental organizations, who actively engage on fire issues; local communities, who 
engage with fire suppression issues; and academics, who actively research fires (Gupta \& Vegelin, 2016; Ishartono \& Raharjo, 2015).

Based on data analysis from 264 respondents, we identify some problems in terms of the level of knowledge and community participation, it can be said that the majority of the community is still lacking in knowledge and the level of participation in the $3 \mathrm{R}$ peat restoration (rewetting, revegetation and revitalization) effort which can be seen from several field findings at the time the research was conducted. Like the canal block that has been made intentionally destroyed by the community just because it is caused by the disturbance of the community sago production process.

Based on the results of data analysis, the next discussion is about the form of benefits felt by the community in peat restoration (3R) based on social (Figure 9), economic (Figure 10) and environmental aspects (Figure 11). In the social aspect, the concern of the community to conserve peatlands (Figure 8) is $74.66 \%$ although this amount is included in the category of benefits perceived by the community in terms of social aspects but is still below average.

This is also evidenced by the results of the analysis of interviews with key informants that there are people who are less concerned with the implementation of restoration, less contributing to restoration, and there are still people who lack knowledge about peat restoration. Likewise, the response of the community in the effort to overcome peatland fires was $83.74 \%$ which was included in the category of large benefits sustainability but below the average response of the community. This is demonstrated by the activity of the Fire Concern Community and the efforts that have been made by the community in maintaining the condition of forests and peatlands to stay wet to prevent peatland fires in the Sungai Tohor Village.

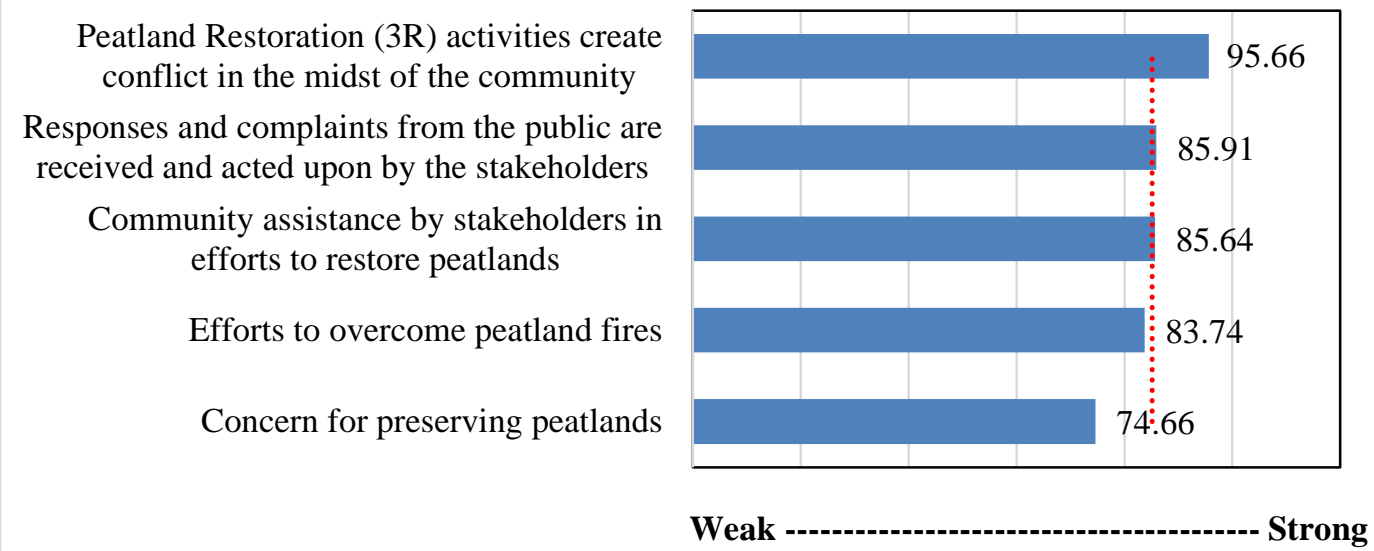

Figure 1. Sustainability Benefits of Peat Restoration (3R) from Social Aspects

Continuity of further benefits is related to community assistance carried out by stakeholders in peatland restoration efforts (Figure 1). As many as $85.64 \%$ of the community stated that the assistance provided a great benefit to the sustainability of peat restoration (3R). This can be seen from the number of researchers, government and non-government institutions that aid in relation to peat restoration (3R) in the Sungai Tohor. The community feels that the assistance provided has provided benefits for the restoration of the Sungai Tohor.

Furthermore, regarding responses to complaints and complaints from the community that were received and acted upon by stakeholders $(85.91 \%)$ who were in the category of providing large benefits above the average category which could be interpreted to have great benefits for the community (Figure 1). Most people feel that the responses and complaints from the community have been accommodated and followed up by stakeholders, including village governments, district governments, government and nongovernment institutions including the Indonesian Peat Restoration Agency (BRG) and various National 
and International researchers. However, this percentage of community response leaves $14.09 \%$ of the public stating that they disagree with this statement. The community with this group stated that some programs created by stakeholders were still not in accordance with the needs of the Sungai Tohor community. This relates to the subsequent community response, which peat restoration (3R) activities caused conflict in the community with a response rate of $96.66 \%$ (highest). The community felt that the resulting conflict was classified as large because it caused community turmoil.

Seen from the community's response that still believes negatively towards programs run by the government or non-governmental organizations, this conflict stems from the community's assumption that the program is only a pilot project because the programs being run do not involve the community so that it often does not fit the needs of the community, and programs that are run only for the benefit of the project owner. These assumptions developed into conflicts with the community, thus impacting the level of community participation to participate in peat restoration $(3 \mathrm{R})$.

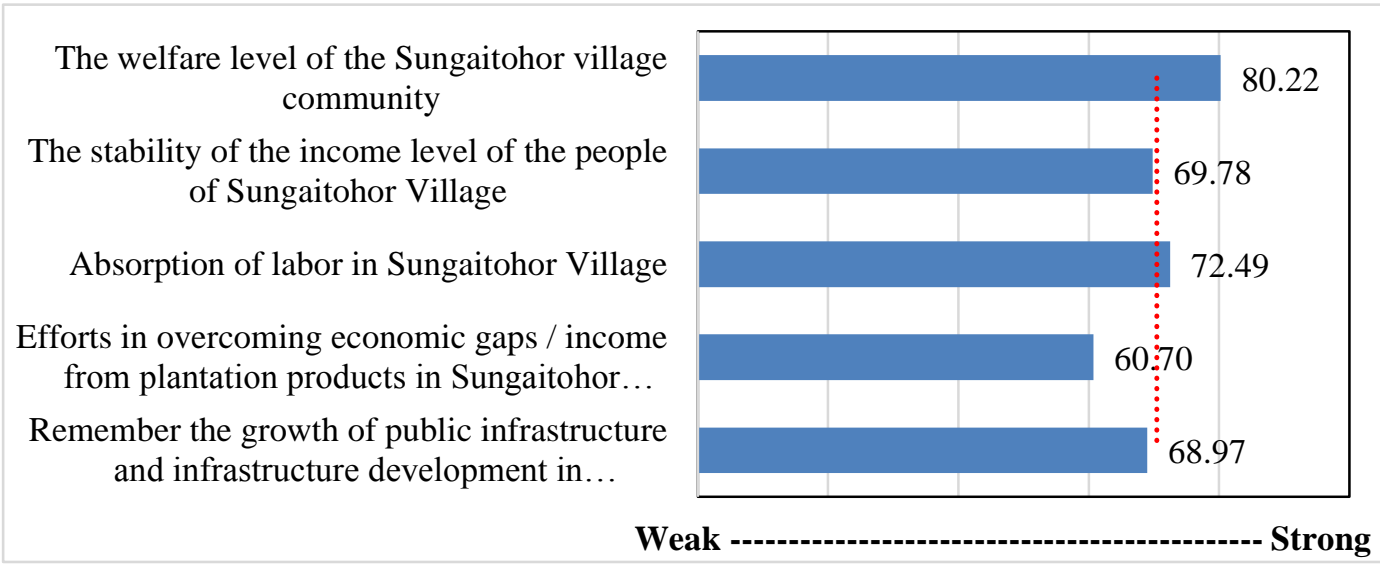

Figure 2. Sustainability Benefits of Peat Restoration from Economic Aspects

The sustainability of the benefits of peat restoration (3R) is then seen from the economic aspects of the community. The results show that $60.70 \%$ (Figure 2) of the Sungai Tohor community seeks to overcome economic disparity or income from plantation products. Although this figure is still below the average of the calculation results, efforts to overcome the economic disparity or income from estate crops are evident. The Sungai Tohor community together formed the EKA (Ekonomi Kreatif Andalan) Institution which was initiated by community leaders of the Sungai Tohor which aims to facilitate the community to be able to develop processed sago products which will have a major impact on increasing the income of the community to be more balanced and minimize disparities.

In addition to EKA, some communities also have private sago gardens and sago processing factories that employ local people. This is in line with the next statement regarding employment in Sungai Tohor Village. A total of $72.49 \%$ of the community revealed that the efforts that have been made in overcoming economic inequality were also evidenced by the absorption of a large workforce that had an impact on the stability of the income level of the Sungai Tohor Village community (69.78\%). For the Sungai Tohor community, this has had a sustainable impact on the benefits of peat restoration which has a large impact on the growth rate of the construction of public facilities and infrastructure $(70.43 \%)$ and the welfare level of the Sungai Tohor village community $(80.22 \%)$. This sustainability can be seen from the improvement of public facilities in the form of canal blocking, concrete roads, trenches and other facilities that provide smooth running for the community in the production process, carrying out daily activities and smoothing the community's economy. 
The degree of sustainability of ecological (conservation) functions, such as the benefits of estate crops on peatlands in the province

Plantations on the Sungaitohor gabut land do not cause air, water and soil pollution

Maintaining biodiversity (sago plantations, rubber, coconut, agriculture, and other flora ecosystems)

The level of compliance with land / space use regulations in the Sungaitohor environment (rates of illegal logging, and illegal...

Health level while living in Sungaitohor village (Does not cause health problems)

The level of compliance with work safety regulations in the forest / peatland environment in Sungaitohor

There are documented procedures that explain efforts to prevent forest fires on peatlands in Sungaitohor

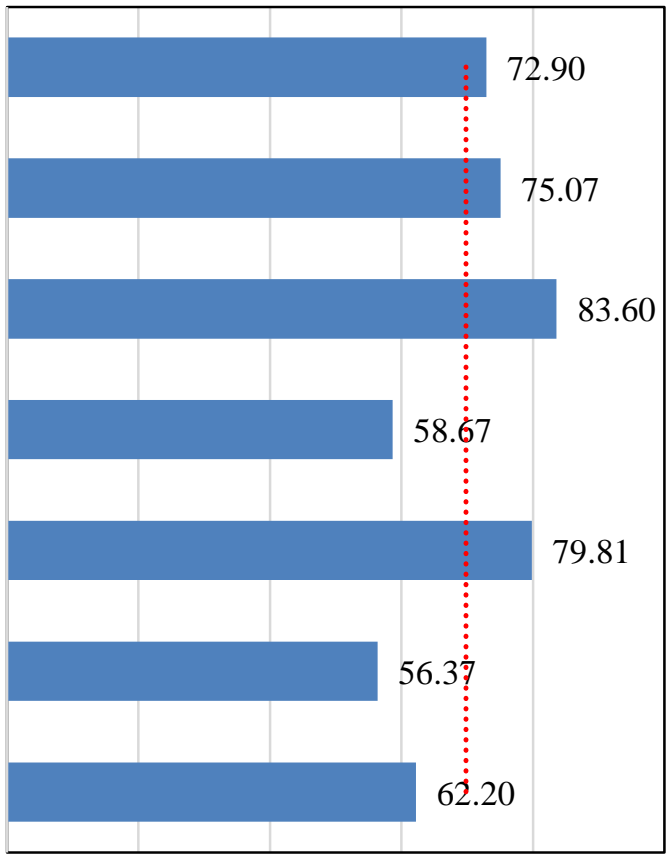

Weak Strong

Figure 3. Sustainability Benefits of Peat Restoration from Environment Aspects

The next discussion is about the sustainability of the benefits of peat restoration on environmental or ecological aspects (Figure 3). On the environmental aspect, researchers found a link between economic aspects on environmental aspects. In terms of economic aspects, developing peatlands by communities which are made as community gardens to produce sago, also provides great benefits for the environment at the level of ecological function sustainability (72.90\%). Land use from this perspective also makes biodiversity more consisting of sago, rubber, coconut, flora and agriculture sectors in Sungai Tohor Village (83.60\%). Peat restoration in the Sungai Tohor is only based on environmental aspects that are not in accordance with community regulations regarding land use $(58.67 \%)$, work safety $(56.37 \%)$, and documented procedures for forest protection. 62.20\%) all of these figures are below the average line. However, in the environmental aspects of land use on peat land does not cause air, air and soil pollution (75.07\%) and health impacts for the community $(79.81 \%)$.

However, such environmental aspects are not only about health, and sustainable land conservation. Economic aspects also have a negative impact with the presence of factories and processing of sago products for the environment. Based on the research results, there are several river points that are directly related to the sago factory on the Sungai Tohor, producing very large sago waste even though it is not currently flowing into the river or community canal, but if it continues it will continue to have an impact on public health, environmental health and the air on the Sungai Tohor.

\section{CONCLUSION}

Conservation of the remaining peatlands in Sungai Tohor village, and sustainable management and restoration of peatlands, requires an integrated cross-sectoral approach that requires transparent dialogue between stakeholders to negotiate complex reciprocal exchanges from environmental, social and 
economic imperatives. The location, land cover and land tenure status of the moratorium protected area, and areas targeted for restoration and rehabilitation, must be communicated transparently and strictly to all stakeholders involved in this initiative.

Based on research findings, it was found that peatland restoration is still not sustainable. The reason is low community participation in peat restoration. It is known that the low participation is caused by the lack of community involvement in decision making and consideration of peat restoration efforts. Then, there are often misunderstandings between stakeholders and community communication. Like the canals that were made intentionally destroyed by the community only because it was caused by disruption of the community sago production process.

Developing livelihoods adapted from wetlands and financially viable agribusiness options is very urgent and important. New models of peatland management require careful analysis of, and research into, the environmental, economic and social results of these alternatives. Coordination between actions at the local scale and planning at a larger scale, especially investment channeling, will be crucial for effective implementation

\section{SUGGESTION}

The government as a power holder must undertake a sectoral approach in the field of peat restoration so that the purpose of sustainable restoration can be realized. This can be done with a discussion of the discussions between stakeholders to negotiate the interests of environmental, social and economic imperative.

Transparency communication between stakeholders can be initiated through the active participation of stakeholders. For this to be realized should be done increasing community participation by involving them in decision making and consideration of peat restoration by observing the social and economic life of the community whose territory is included in the program Peat restoration.

\section{BIBLIOGRAPHY}

[1]. Creswell, J. W. (2010). Mapping The Developing Landscape Of Mixed Methods Research. Sage Handbook Of Mixed Methods In Social \& Behavioral Research, 2, 45-68.

[2]. Gupta, J., \& Vegelin, C. (2016). Sustainable Development Goals And Inclusive Development. International Environmental Agreements: Politics, Law And Economics. Https://Doi.Org/10.1007/S10784-016-9323-Z

[3]. Hariyanto, B. (2016). Manfaat Tanaman Sagu (Metroxylon Sp) Dalam Penyediaan Pangan Dan Dalam Pengendalian Kualitas Lingkungan. Jurnal Teknologi Lingkungan. Https://Doi.Org/10.29122/Jtl.V12i2.1246

[4]. Ishartono \& Raharjo, S. T. (2015). Sustainable Development Goals (Sdgs) Dan Pengentasan Kemiskinan. Social Work Jurnal.

[5]. Jong, F. S. (2018). An Overview Of Sago Industry Development, 1980s-2015. In Sago Palm: Multiple Contributions To Food Security And Sustainable Livelihoods. Https://Doi.Org/10.1007/978-981-10-5269-9_6 
[6]. Laufa, T., \& Kavanamur, D. (2008). Biodiplomacy Of The Sago Palm In Papua New Guinea - A Systems Thinking Approach. Contemporary Png Studies.

[7]. Metaragakusuma, A. P., Katsuya, O., \& Bai, H. (2016). An Overview Of The Traditional Use Of Sago For Sago-Based Food Industry In Indonesia. Kne Life Sciences. Https://Doi.Org/10.18502/Kls.V3i3.382

[8]. Ming, R. Y. C., Sobeng, Y., Zaini, F., \& Busri, N. (2018). Suitability Of Peat Swamp Areas For Commercial Production Of Sago Palms: The Sarawak Experience. In Sago Palm: Multiple Contributions To Food Security And Sustainable Livelihoods. Https://Doi.Org/10.1007/978-981-105269-9_7

[9]. Muhidin, Leomo, S., Alam, S., \& Wijayanto, T. (2016). Comparative Studies On Different Agroecosystem Base On Soil Physicochemical Properties To Development Of Sago Palm On Dryland. International Journal Of Chemtech Research.

[10]. Nusawakan, M., Kunu, P., \& Luhukay, M. (2017). Kondisi Lahan Tumbuhan Sagu Di Desa Rumahkay Kecamatan Amalatu Kabupaten Seram Bagian Barat Provinsi Maluku. Jurnal Budidaya Pertanian. Https://Doi.Org/10.30598/Jbdp.2017.13.2.84

[11].Sharma, R. K., \& Kharub, M. (2015). Qualitative And Quantitative Evaluation Of Barriers Hindering The Growth Of Msmes. International Journal Of Business Excellence, 8(6), 1-17. Https://Doi.Org/10.1504/Ijbex.2015.072307 